\title{
Factors affecting the potassium concentration at the mucosal surface of the proximal and the distal colon of guinea pig
}

\author{
U Kück-Biere, W von Engelhardt
}

\begin{abstract}
$\mathrm{K}^{+}$concentrations were measured in vitro with $\mathrm{K}^{+}$sensitive microelectrodes in the microclimate at the luminal cell surface of the colon of guinea pigs. The serosal $\mathrm{K}^{+}$concentration was mostly $5.4 \mathrm{mmol} / 1$, the mucosal $\mathrm{K}^{+}$ concentrations were changed $(0,5,50$, or 70 mmol/l). Under control conditions $\mathbf{K}^{+}$concentrations in the microclimate of the proximal colon were also low (6-9 $\mathrm{mmol} / \mathrm{l})$ and rather independent from $\mathrm{K}^{+}$concentrations in the bulk luminal solution. In the distal colon $\mathrm{K}^{+}$ concentrations in the microclimate increased from $3.7 \mathrm{mmol} / 1$ when no $\mathrm{K}^{+}$was in the luminal solution, up to $22 \mathrm{mmol} / \mathrm{l}$ when the mucosal $\mathrm{K}^{+}$ concentration was $70 \mathrm{mmol} / \mathrm{l}$. Attempts to decrease $\mathrm{K}^{+}$conductance of the apical membrane with $\mathrm{Ba}^{++}$, to impair $\mathrm{K}^{+}$transport with ouabain and to increase the paracellular shunt with deoxycholic acid did not affect $\mathrm{K}^{+}$concentrations in the microclimate of the proximal colon but decreased $\mathrm{K}^{+}$concentrations in the distal colon. When valinomycin or triaminopyrimidine were added to the mucosal solution at high $\mathrm{K}^{+}$concentrations in the luminal solutions the $\mathrm{K}^{+}$concentration in the microclimate was raised. At low luminal $\mathrm{K}^{+}$concentrations valinomycin had no effect, triaminopyrimidine significantly diminished $\mathrm{K}^{+}$concentrations at the cell surface. Regional differences in paracellular shunt conductance and in the preepithelial diffusion barrier are thought to be responsible for the observed differences between the proximal and the distal colon. Obviously, however, further unknown mechanisms have to be involved.
\end{abstract}

The mucus layer at the luminal surface of the colon in guinea pig is a region where $\mathrm{pH}$ values ${ }^{1}$ and $\mathrm{K}$ concentrations ${ }^{2}$ are maintained within a narrow range. These values can be very different from those in the bulk luminal fluid. $\mathrm{H}^{-}$and $\mathrm{K}$ concentrations in this microclimate are independent from the concentrations in the luminal solution, and the concentrations are closer to the respective concentrations at the serosal side of the epithelium. It was suggested $^{2}$ that a high pre-epithelial diffusion barrier and a high paracellular permeability may be major factors determining ion concentrations in the microclimate at the surface of the colonic mucosa, and that epithelial transport mechanisms may be less important. The aim of this study was to investigate the effects of alterations of the paracellular shunt and of the $\mathrm{K}^{+}$conductance of the apical membrane on the $\mathrm{K}$ microclimate.

\section{Methods}

ANIMALS AND EXPERIMENTAL PROCEDURES Male guinea pigs (Schlieker, Warbsen), weighing between 400 and $500 \mathrm{~g}$, were fed ad libitum with a commercial diet (Altromin 3022, Lage) and were allowed free access to tap water supplemented with vitamin $C$. They were anaesthetised by an intramuscular injection $(0.1 \mathrm{ml} / 100 \mathrm{~g}$ body weight of a 1:1 mixture of $200 \mathrm{mg} / \mathrm{ml}$ xylazine (Rompun ${ }^{\circledR}$, Bayer, Leverkusen) and $100 \mathrm{mg} / \mathrm{ml}$ ketamine hydrochloride (Vetalar ${ }^{\circledR}$, Parke Davis, München)). After excision of the colon the animals were killed by intracardial injection of $0.5 \mathrm{ml} T 61^{\circledR}(0.2 \mathrm{~g} / \mathrm{ml}$ embutramid, $0.05 \mathrm{~g} / \mathrm{ml}$ mebe-zonjum-iodide, Hoechst, Frankfurt).

The colon was resected from the anaesthetised animals and put immediately into oxygenated Krebs-Ringer solution at room temperature (Table I). Proximal and distal colon segments ${ }^{1}$ were opened along the mesenteric border, and their contents were removed by floating the tissue in the solution. The muscle layers were 'subtotally' stripped by a method similar to that described by Nellans et al. ${ }^{3}$ Care was taken to keep the mucus layer intact on the epithelium. For further preparation of the proximal colon only areas between taenia free of Payer's patches were used. The tissue was mounted in an in vitro chamber and fixed by six small steel pins, mucosal side up, over a $7.0 \mathrm{~mm}$ opening of an acrylic lid. The method has been described recently. ${ }^{2}$ An acrylic disc was placed on the mucosa and was sealed with a layer of silicon (Baysilon, Bayer, Leverkusen). Warm $\left(37^{\circ} \mathrm{C}\right)$ Krebs-Ringer solution, previously gassed with $95 \% \mathrm{O}_{2}$ and $5 \% \mathrm{CO}_{2}$, was filled to the serosal side of the epithelium. The mucosal solution, heated by a water jacket, was perfused at $1-2 \mathrm{ml} / \mathrm{min}$.

TABLE I Composition of test solutions ( $\mathrm{mmol} / \mathrm{l}$ ). The osmolality was adjusted by addition of mannitol to 300 mosmol/kg

\begin{tabular}{|c|c|c|c|c|c|}
\hline & \multicolumn{4}{|c|}{ 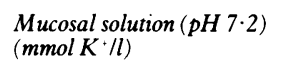 } & \multirow{2}{*}{$\begin{array}{l}\text { Serosal solution } \\
(\text { Krebs-Ringer, } \\
\text { pH 7.4) }\end{array}$} \\
\hline & 0 & 5 & 50 & 70 & \\
\hline $\mathrm{CaCl}_{2}$ & $2 \cdot 5$ & $2 \cdot 5$ & $2 \cdot 5$ & $2 \cdot 5$ & $1 \cdot 2$ \\
\hline $\mathrm{MgCl}_{2}$ & $7 \cdot 5$ & $7 \cdot 5$ & $7 \cdot 5$ & $7 \cdot 5$ & $1 \cdot 2$ \\
\hline $\mathrm{NaHCO}$ & $20 \cdot 0$ & $20 \cdot 0$ & $20 \cdot 0$ & - & $21 \cdot 0$ \\
\hline $\mathrm{KHCO}_{3}$ & - & - & - & $20 \cdot 0$ & - \\
\hline $\mathrm{KCl}$ & - & $5 \cdot 0$ & $10 \cdot 0$ & $10 \cdot 0$ & $5 \cdot 4$ \\
\hline $\mathrm{NaCl}$ & $10 \cdot 0$ & $5 \cdot 0$ & - & - & $113 \cdot 6$ \\
\hline Na-acetate & 60.0 & $60 \cdot 0$ & $60 \cdot 0$ & $60 \cdot 0$ & - \\
\hline Na-butyrate & 10.0 & $10 \cdot 0$ & $10 \cdot 0$ & $10 \cdot 0$ & - \\
\hline $\mathrm{Na}$-propionate & 10.0 & $10 \cdot 0$ & 10.0 & $10 \cdot 0$ & - \\
\hline $\mathrm{Na}_{2} \mathrm{HPO}_{4}$ & $10 \cdot 0$ & $10 \cdot 0$ & - & - & $2 \cdot 4$ \\
\hline $\mathrm{NaH}_{2} \mathrm{PO}_{4}$ & $20 \cdot 0$ & $20 \cdot 0$ & - & - & 0.6 \\
\hline $\mathrm{K}_{2} \mathrm{HPO}_{4}$ & - & - & $10 \cdot 0$ & $10 \cdot 0$ & - \\
\hline $\mathrm{KH}_{2} \mathrm{PO}_{4}$ & - & - & 20.0 & $20 \cdot 0$ & - \\
\hline Glucose & - & - & - & - & $10 \cdot 0$ \\
\hline
\end{tabular}




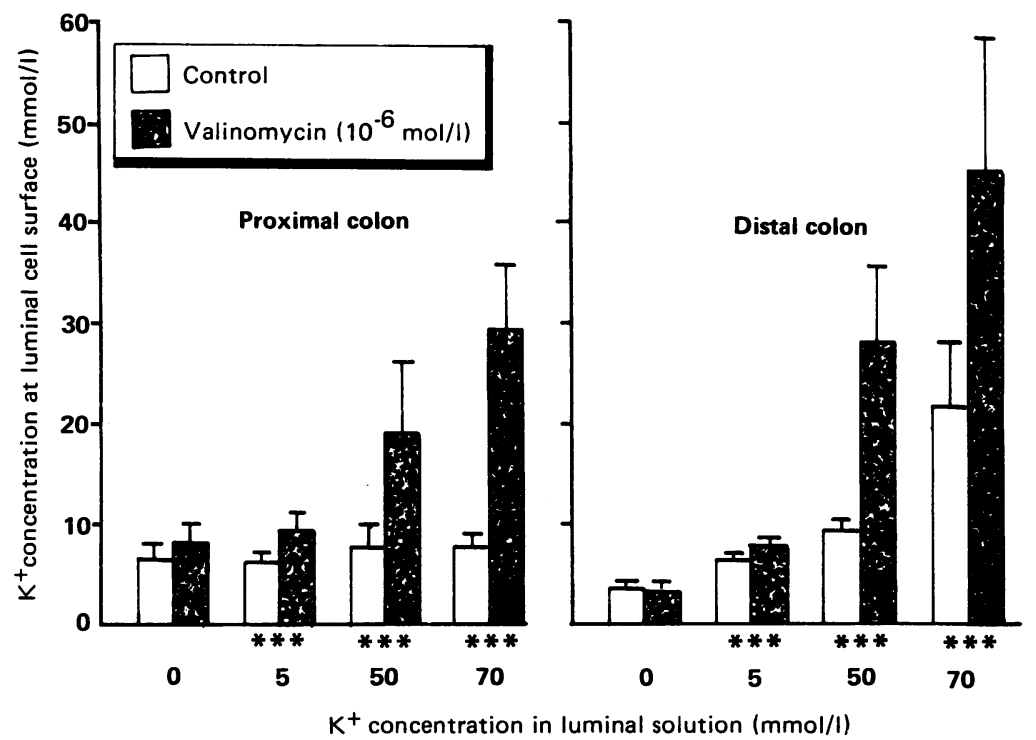

Figure 1: Influence of valinomycin $\left(10^{\circ} \mathrm{mol} / \mathrm{l}\right)$ on $\mathrm{K}$ ' concentrations at the luminal cell surface of the proximal and the distal colon. $K$ ' concentration in the serosal solution was $5 \cdot 4 \mathrm{mmol} / \mathrm{l}$. $n=3$ for the proximal and distal colon; values are calculated from 4-13 measurements. $\star \star \star p<0 \cdot 001$.
$\mathrm{K}_{\mathrm{K} / \mathrm{Ca}}, \mathrm{K}_{\mathrm{K} / \mathrm{Mg}}$ ) were calculated using the formula of Dagostino and Lee.? The characteristics and the selectivity coefficients for our electrodes have been given recently. ${ }^{2}$ The $K^{*}$ concentrations were calculated from activity coefficients. ${ }^{8}$ The selectivity of the electrodes was not affected by $\mathrm{Ba}^{+*}$, deoxycholic acid, triaminopyrimidine, or valinomycin.

The electrodes were connected through an $\mathrm{Ag} / \mathrm{AgCl}$ junction (WPI, New Haven) to a high impedance electrometer (WPI, FD 223). A $\mathrm{Hg}$ /calomel electrode with an Agar- $\mathrm{KCl}$ bridge (saturated $\mathrm{KCl}$ and $3 \%$ Agar) was used as reference electrode. Signals were recorded on a strip chart recorder (Kipp and Zonen, BD 40, Delft).

The electrodes were mounted on a micromanipulator (Leitz, Wetzlar), and were advanced towards the mucosa under microscopic control (Wild, Heerburg, 75×). It was not possible to determine visually when the electrode had reached the epithelial cell surface. The cell surface was considered to be reached when further electrode advance was not associated with voltage change, or when electrical noise suggested that the cellular surface had been reached. ${ }^{9}$

Table I. The $\mathrm{pH}$ of all solutions was adjuste $7 \cdot 2$ by $1 \mathrm{~N} \mathrm{NaOH}$ or $1 \mathrm{~N} \mathrm{HCl}$. The serosal Krebs-Ringer bicarbonate-solution ${ }^{4}$ was adjusted to $\mathrm{pH} 7 \cdot 4$. In experiments with varying luminal $\mathrm{K}^{-}$concentrations $\mathrm{K}^{+}$was exchanged for $\mathrm{Na}^{+}$. In the luminal solutions where $\mathrm{Ba}^{++}$was added phosphate was replaced by $20 \mathrm{mmol} / \mathrm{l}$ Hepes; $\mathrm{Ca}^{+}$concentration was reduced to 1 $\mathrm{mmol} / \mathrm{l}$ and $\mathrm{Mg}^{+*}$ to $3 \mathrm{mmol} / \mathrm{l}$. Valinomycin and triaminopyrimidine were added to the control solution. The addition of triaminopyrimidine and the necessary titration to $\mathrm{pH} 6$ with $\mathrm{HCl}$ increased the osmolality to $340 \mathrm{mosmol} / \mathrm{kg}$. The respective control solution in this study was also adjusted to $\mathrm{pH} 6$ and $340 \mathrm{mosmol} / \mathrm{kg}$ by titration and by adding mannitol. In solutions containing deoxycholic acid (DCA), $\mathrm{Ca}^{+-}$and $\mathrm{Mg}^{++}$concentrations were decreased to 1 and $3 \mathrm{mmol} / \mathrm{l}$ respectively, 2,4,6-triaminopyrimidine was obtained from Sigma Chemie (St Louis), valinomycin and ouabain from Serva (Heidelberg), deoxycholic acid from Merck (Darmstadt) and $\mathrm{D}-1-{ }^{14} \mathrm{C}$ mannitol from Amersham-Buchler (Braunschweig). All other chemicals were purchased from Fluka (Neu-Ulm).

Concentrations of $\mathrm{K}^{+}$and $\mathrm{Na}^{+}$in the solutions were estimated by flame photometry (Radiometer FLM 3, Copenhagen) and the osmolality by freezing point depression (Roebling, Berlin).

POTASSIUM SELECTIVE MICROELECTRODES The potassium selective microelectrodes were constructed by Duffey's method, ${ }^{5}$ using potassium selective liquid exchanger (Fluka 60031). The outside of the electrode tip was sometimes coloured black (Edding 3000) to make visual control easier.

Before each experiment the electrodes were calibrated in $1.5,15$, and $150 \mathrm{mmol} / 1 \mathrm{KCl}$ solutions as well as against the test solutions. The electrode selectivity for $\mathrm{K}^{-}$was tested by the separate solution technique ${ }^{6}$ using $\mathrm{Na}^{+}, \mathrm{K}^{+}$, $\mathrm{Mg}^{++}$, and $\mathrm{Ca}^{++}$. Selectivity coefficients $\left(\mathrm{K}_{\mathrm{K} / \mathrm{Na}}\right.$,
PERMEABILITY OF THE COLONIC MUCOSA

To evaluate changes in the paracellular permeability ${ }^{14} \mathrm{C}$-mannitol permeation rates were measured. ${ }^{10}$ Experiments were performed in incubation chambers similar to those described by Lukie et al. ${ }^{11}$ The aperture exposed $0.39 \mathrm{~cm}^{2}$ of tissue to the solutions. The incubation beaker (mucosal side) was filled with $20 \mathrm{ml}$ KrebsRinger buffer (KRB). $0.75 \mathrm{ml} \mathrm{KRB}$ solution containing $20 \mathrm{mmol} / \mathrm{l}$ unlabelled mannitol were added to the serosal side. Hydrostatic pressure gradients were avoided by adjusting the central cylinder. The rate of stirring was always 500 rpm. The tissue was prepared as described above. Experiments started with a pre-incubation period of 30 minutes in the unlabelled solution. Then the plug with the tissue was transferred to another beaker containing the test solution with $2.5 \mu \mathrm{Ci} / 1{ }^{14} \mathrm{C}$-mannitol. After 30 minutes aliquots of $0.5 \mathrm{ml}$ were taken from mucosal and serosal solutions. Each sample was mixed with $5 \mathrm{ml}$ instagel II and radioactivity was measured in a liquid scintillation counter $(460 \mathrm{C}$, Packard).

The permeability for mannitol ( $P$ in $\mathrm{cm} / \mathrm{s}$ ) was calculated as the ${ }^{14} \mathrm{C}$-activity in the serosal fluid after 30 minutes divided by the mean ${ }^{1+} \mathrm{C}$-activity

TABLE II Mannitol permeability $(P, \mathrm{~cm} / \mathrm{s})$ of the epithelium of the proximal and the distal colon

\begin{tabular}{lcr}
\hline & \multicolumn{2}{c}{ Mannitol permeability $(\mathrm{cm} / \mathrm{s})$} \\
\cline { 2 - 3 } & Proximal colon & Distal colon \\
\hline P control & $3.4(1 \cdot 8) \times 10^{\circ}$ & $3.9(1 \cdot 7) \times 10^{\circ}$ \\
P DCA & $15.0(0.2) \times 10^{\circ} \star \star \star$ & $12 \cdot 0(0.4) \times 10^{\circ \star \star \star}$ \\
P TAP & $3.9(0.9) \times 10^{\circ}$ & $3.3(2 \cdot 7) \times 10^{\circ}$ \\
\hline
\end{tabular}

Control values with Krebs-Ringer solution on both sides. Deoxycholic acid (DCA) (6 mmol/1) and triaminopyrimidine (TAP) $(20 \mathrm{mmol} / 1, \mathrm{pH} \mathrm{6.0,340} \mathrm{mosmol} / \mathrm{kg})$ were added to the luminal solution. $\mathrm{n}=3$ for the proximal and distal colon; values are calculated from 8-9 measurements (for $P$ control of the proximal colon $n=14$ with 42 measurements). ${ }^{\star \star \star} p<0 \cdot 001$. FOR MANNITOL 


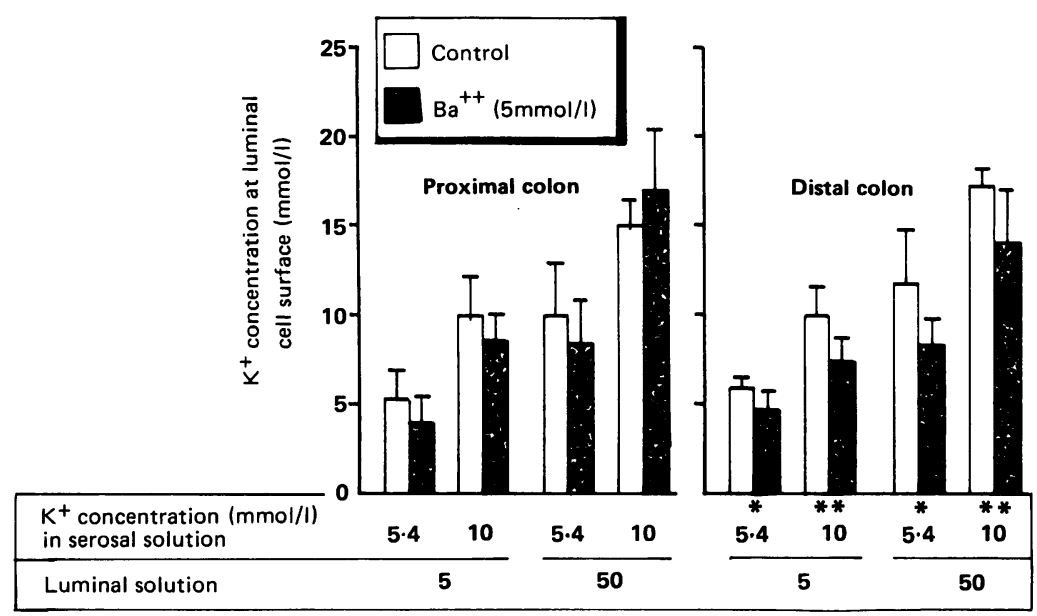

Figure 2: Influence of luminal $\mathrm{Ba}^{++}(5 \mathrm{mmolll})$ on $\mathrm{K}^{+}$concentrations at the luminal cell surface of the proximal and the distal colon. $n=4$ for the proximal and distal colon; values are calculated from $7-13$ measurements. ${ }^{\star} p<0 \cdot 05 ;{ }^{\star \star} p<0 \cdot 01$.

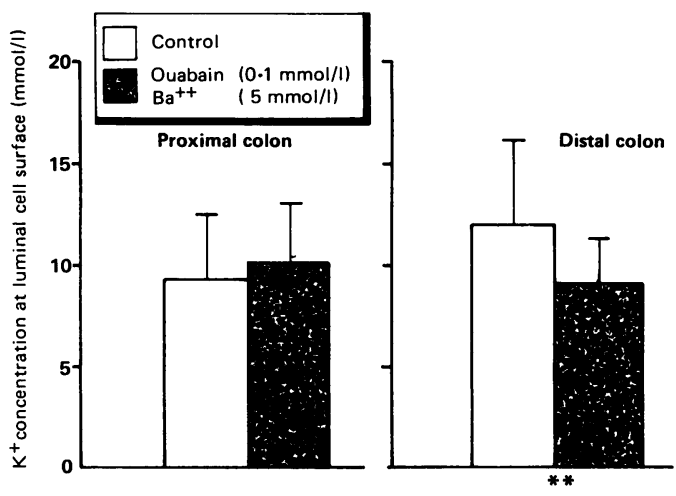

Figure 3: Influence of ouabain $(0 \cdot 1 \mathrm{mmol} / \mathrm{l})$ in the serosal and $\mathrm{Ba}^{++}(5 \mathrm{mmol} / \mathrm{l})$ in the serosal and mucosal solution on $\mathrm{K}$ concentrations at the luminal cell surface of the proximal and the distal colon. $K^{+}$concentration in the serosal solution was $5.4 \mathrm{mmol} / \mathrm{l}$, and in the mucosal solution $50 \mathrm{mmol} / \mathrm{l} . \mathrm{n}=7$ for the proximal and distal colon; values are calculated from 22-68 measurements. $(\star \star p<0.01)$.

in the mucosal fluid; tissue area $\left(0.39 \mathrm{~cm}^{2}\right)$ and time of incubation (1800 s) were taken into account.

Results are expressed as mean with standard deviation (SD). Differences were analysed using

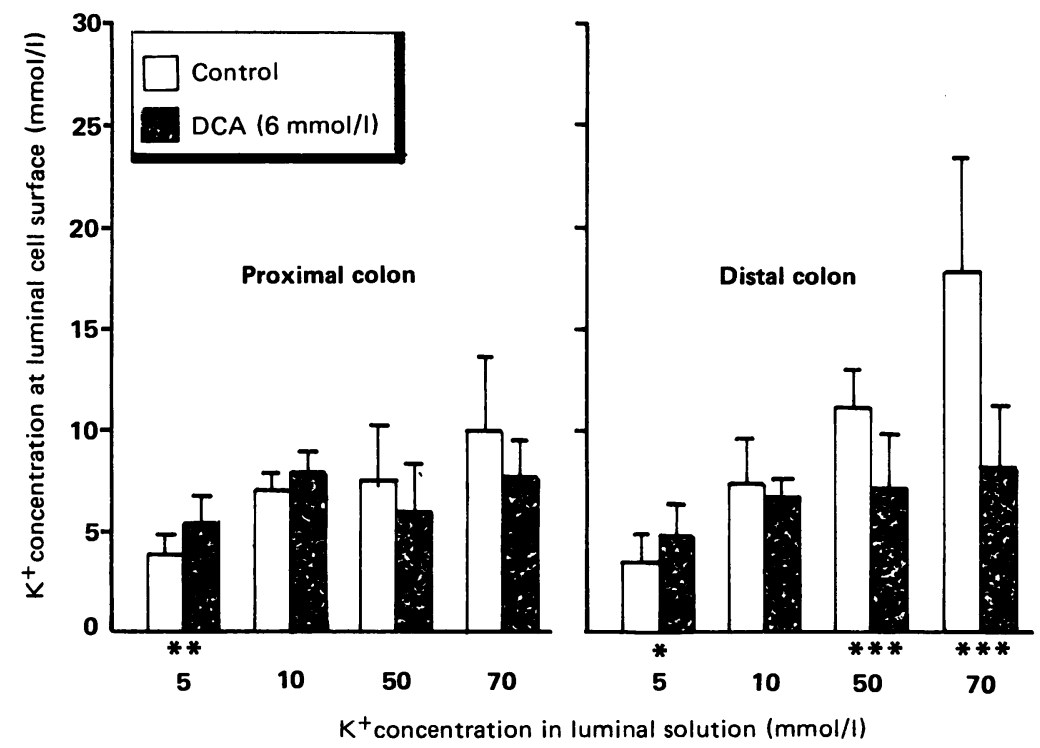

Figure 4: Influence of luminal deoxycholic acid (DCA, $6 \mathrm{mmol} / \mathrm{l})$ on $\mathrm{K}^{\prime}$ concentrations at the luminal cell surface of the proximal and the distal colon. $K$ ' concentration in the serosal solution was $5.4 \mathrm{mmol} / \mathrm{l} . \mathrm{n=4}$ for the proximal and distal colon; values are calculated from $8-18$ measurements. ${ }^{\star} p<0.05 ;{ }^{\star \star} p<0.01 ;{ }^{\star \star}{ }^{\star} p<0.001$.
Student's $t$ test. The capital $\mathrm{N}$ indicates the number of animals.

\section{Results}

$\mathrm{K}^{+}$CONCENTRATIONS AT THE LUMINAL SURFACE AFTER ALTERATION OF THE K CONDUCTANCE OF THE APICAL MEMBRANE

Increase of apical membrane permeability with valinomycin $\left(10^{-6} \mathrm{moll} / \mathrm{l}\right)$

Addition of the ionophore valinomycin to the luminal solution leads to an increase in the $\mathrm{K}^{+}$ conductance of the apical membrane. ${ }^{12}$

In the control experiments without valinomycin, $\mathrm{K}^{+}$concentrations at the luminal surface of the proximal colon $(6.7(1.8) \mathrm{mmol} / \mathrm{l}) \mathrm{did}$ not change with increasing luminal $\mathrm{K}^{+}$concentrations from 0 to $70 \mathrm{mmol} / \mathrm{l}$. In the distal colon, the $\mathrm{K}^{+}$concentration in the microclimate increased significantly in the control group from $3 \cdot 7(0 \cdot 6)$ $\mathrm{mmol} / \mathrm{l}$, when no $\mathrm{K}^{+}$was in the luminal solution, up to $21.5(6.5)$ at a $\mathrm{K}^{+}$concentration of 70 $\mathrm{mmol} / \mathrm{l}$ (Fig 1). Data are similar to those of a preceding study. ${ }^{2}$

Addition of valinomycin to the luminal solution resulted in significantly higher $\mathrm{K}^{+}$concentrations at the luminal surface in the proximal and in the distal colon when the $\mathrm{K}^{+}$concentrations in the luminal solution were higher than 5 $\mathrm{mmol} / \mathrm{l}$; values increased to twice or three times the controls (Fig 1).

\section{Decrease of apical $\mathrm{K}^{+}$conductance with $\mathrm{Ba}^{++}$ $(5 \mathrm{mmolll})$}

To lower the $\mathrm{K}^{+}$conductance of the apical membrane, the $\mathrm{K}^{+}$channel blocker barium was added to the luminal solution. Two different serosal $(5.4$ and $10 \mathrm{mmol} / \mathrm{l})$ and two luminal (5 and $50 \mathrm{mmol} / \mathrm{l}) \mathrm{K}^{+}$concentrations were used.

In the proximal colon, $\mathrm{Ba}^{++}$had no significant influence on the $\mathrm{K}^{+}$concentrations at the luminal surface (Fig 2). In the distal colon, on the other hand, $\mathrm{K}^{+}$concentrations in the microclimate were decreased slightly.

\section{$\mathrm{K}^{+}$CONCENTRATIONS AT THE LUMINAL SURFACE AFTER INHIBITION OF $\mathrm{Na}-\mathrm{K}$ ATPase AND $\mathrm{K}^{+}$CONDUCTANCE}

Ouabain $\left(10^{-4} \mathrm{~mol} / \mathrm{l}\right)$ in the serosal solution plus $\mathrm{Ba}^{++}(5 \mathrm{mmol} / \mathrm{l})$ in the serosal and the mucosal solution had no effect on the $\mathrm{K}^{+}$concentrations in the microclimate of the proximal colon (Fig 3). In the distal colon $\mathrm{K}^{+}$concentrations in the microclimate were decreased by ouabain treatment. The effect of $\mathrm{Ba}^{++}$plus ouabain was not different from the effect of $\mathrm{Ba}^{++}$added to the mucosal solution alone (Fig 2).

\section{$\mathrm{K}^{+}$CONCENTRATIONS AT THE LUMINAL SURFACE AFTER ALTERATION OF} PARACELLULAR PERMEABILITY

Increase of paracellular permeability with deoxycholic acid (6 mmol/l)

After addition of deoxycholic acid to the luminal 


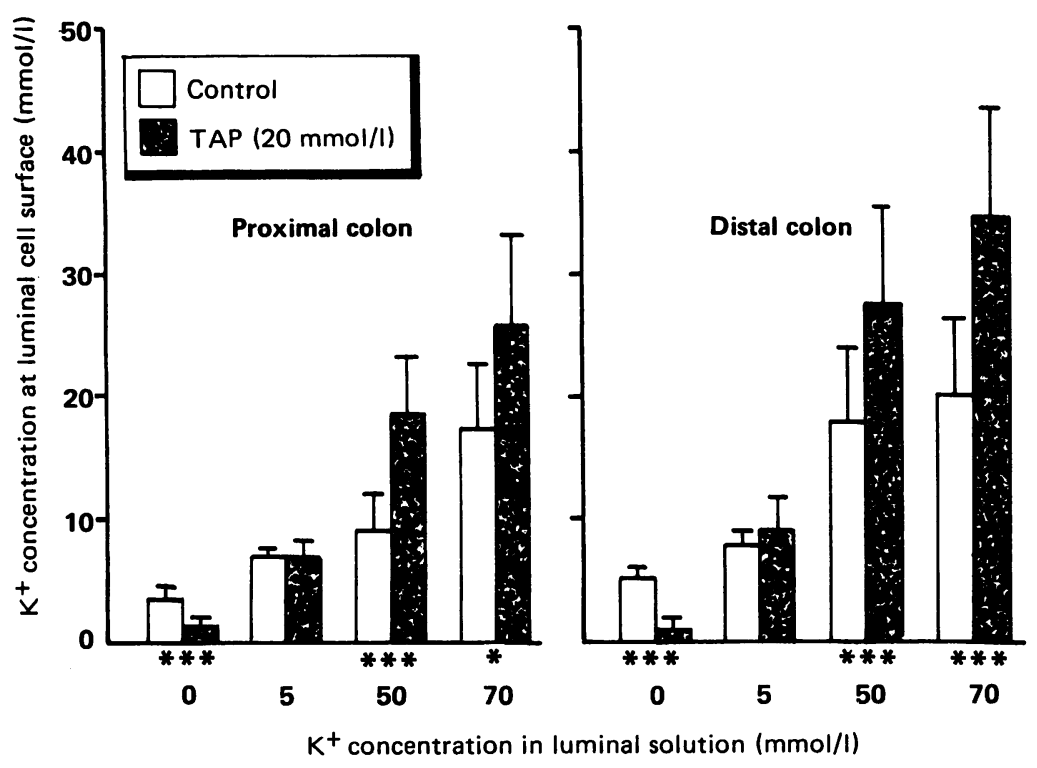

Figure 5: Influence of triaminopyrimidine (TAP, $20 \mathrm{mmol} / \mathrm{l})$ compared to the control solution (pH 6.0 and 340 mosmol $/ \mathrm{kg}$ ) on $\mathrm{K}^{+}$concentrations at the luminal cell surface of the proximal and the distal colon. $K^{\prime}$ concentration in the serosal solution was $5 \cdot 4 \mathrm{mmol} / \mathrm{l} . n=4$ for the proximal and distal colon; values are calculated from $7-18$ measurements. ${ }^{\star} p<0 \cdot 05$ $\star \star \star p<0.001$.

\section{Discussion}

The present experiments confirm our earlier observations $^{2}$ that in the proximal colon of guinea pig under control conditions $\mathrm{K}^{+}$concentrations in the luminal microclimate are more or less constant near $8 \mathrm{mmol} / \mathrm{l}$ when $\mathrm{K}^{+}$concentrations in the luminal solution were increased (0-70 $\mathrm{mmol} / \mathrm{l})$ and the concentrations in the serosal solutions were constant at $5.4 \mathrm{mmol} / \mathrm{l}$. In the more tight distal colon, on the other hand, $\mathrm{K}$ concentrations in the microclimate increased gradually when $\mathrm{K}^{+}$concentrations in the luminal solution were raised (Figs 1, 4, 5). In our earlier studies we had concluded that the low $\mathrm{K}^{+}$ concentrations in the microclimate at the luminal surface of the colon may be maintained by a high pre-epithelial diffusion barrier and a low resistance of the paracellular shunt. ${ }^{2}$ It was assumed that the transcellular $\mathrm{K}^{+}$transport is of minor importance in the proximal colon, but it may have a certain influence in the distal colon. This view was supported by the findings of the present study, where drugs were added to alter the $\mathrm{K}^{+}$ conductance of the apical membrane, the transcellular $\mathrm{K}^{+}$transport or the paracellular permeability of the colonic epithelium.

solution $\mathrm{K}^{+}$concentrations at the luminal cell surface approach more closely $\mathrm{K}^{+}$concentrations of the serosal solution. In the proximal colon only the tendency of such a change was seen; in the distal colon this effect was significantly higher when the luminal $\mathrm{K}^{+}$concentration differed from that of the serosal solution (Fig 4).

Decrease of paracellular permeability with 2,4,6triaminopyrimidine ( $20 \mathrm{mmol} / \mathrm{l}$ )

Triaminopyrimidine increases the resistance of the gall bladder, a model for leaky epithelia, by blocking cation selective channels within the tight junctions. ${ }^{13} \mathrm{~A}$ concentration of $20 \mathrm{mmol} / \mathrm{l}$ at $\mathrm{pH} 6.0$ is necessary for this effect.

In control experiments it was shown that the lower $\mathrm{pH}$ and the higher osmolality had no effect on the $\mathrm{K}^{+}$concentrations at the luminal cell surface compared with the solutions with $\mathrm{pH} 7 \cdot 2$ and $300 \mathrm{mosmol} / \mathrm{kg}$. After addition of triaminopyrimidine $\mathrm{K}^{+}$concentrations in the luminal microclimate approached more closely the $\mathrm{K}^{+}$ concentrations in the bulk luminal solution (Fig 5). When no $\mathrm{K}^{+}$was in the luminal solution $\mathrm{K}^{+}$ concentrations in the microclimate decreased to near $2.5 \mathrm{mmol} / \mathrm{l}$. When concentrations in the bulk solutions were similar on both sides of the epithelium ( 5 and $5.4 \mathrm{mmol} / \mathrm{l}$ ) concentrations at the luminal surface did not change. At higher $\mathrm{K}^{+}$ concentrations in the luminal solution ( 50 and 70 $\mathrm{mmol} / \mathrm{l}), \mathrm{K}^{+}$concentrations in the microclimate increased significantly compared to control without triaminopyrimidine.

Effect of deoxycholic acid and triaminopyrimidine on mannitol permeability of the colonic epithelium In the proximal and the distal colon of guinea pig deoxycholic acid caused highly significant $(p<0.001)$ increases in mannitol permeability. Adding triaminopyrimidine to the luminal solution, however, did not produce a decrease in mannitol permeability (Table II).

\section{FACTORS AFFECTING THE $\mathrm{K}^{+}$}

CONDUCTANCE OF THE APICAL MEMBRANE OR THE TRANSCELLULAR $\mathrm{K}^{+}$TRANSPORT Active $\mathrm{K}^{+}$secretion and active $\mathrm{K}^{+}$absorption have been shown in the distal colon of rabbits and rats. ${ }^{14-19}$ The addition of the $\mathrm{K}^{+}$channel blocker $\mathrm{Ba}^{++}$to the mucosal solution decreased active $\mathrm{K}^{+}$secretion ${ }^{20}$ indicating that $\mathrm{K}^{+}$secretion involves a $\mathrm{K}^{+}$exit out of the cell through $\mathrm{Ba}^{++}$ blockable $\mathrm{K}^{+}$channels in the apical membrane.

The small effect of $\mathrm{Ba}^{++}$on $\mathrm{K}^{+}$concentrations in the microclimate in the present study, however, indicates that the $\mathrm{K}^{+}$conductance of the apical membrane under normal conditions is too small to considerably affect the $\mathrm{K}^{+}$concentrations in the microclimate. In the proximal colon of the guinea pig, luminal $\mathrm{Ba}^{++}$as well as serosal $\mathrm{Ba}^{++}$plus ouabain had no effect on $\mathrm{K}^{+}$concentrations in the microclimate. In the distal colon, $\mathrm{Ba}^{++}$decreased $\mathrm{K}^{+}$concentrations in the microclimate under both experimental conditions (Figs 2, 3),

$\mathrm{K}^{+}$concentrations at the luminal cell surface increased significantly (Fig 1) when valinomycin was added; valinomycin is expected to increase the $\mathrm{K}^{+}$permeability of the apical membrane. ${ }^{12}$ The increase was especially marked when the $\mathrm{K}^{+}$ concentrations in the bulk luminal solution were high.

We may conclude that in the proximal colon of the guinea pig under our experimental conditions transcellular $\mathrm{K}^{+}$transport does not seem to play a major role in maintaining $\mathrm{K}^{+}$concentrations in the microclimate; in the distal colon, on the other hand, there seems to be a certain influence of $\mathrm{K}^{+}$secretion or absorption on $\mathrm{K}^{+}$ concentrations in the microclimate.

A number of questions arise from the foregoing findings. For instance, an increase of the $\mathrm{K}^{+}$concentration in the microclimate by means of a raised apical $\mathrm{K}^{+}$conductance would result in a depolarisation of the apical membrane, and 
thus would diminish the driving force for $\mathrm{K}^{+}$out of the cell. Furthermore, a higher $\mathrm{K}$ - concentration in the microclimate would raise the concentration gradient across the epithelium; the transepithelial potential difference, on the other hand, would be diminished. Blocking the $\mathrm{K}$ channels in the apical membrane should result in contrary alterations. Interrelationships between such opposing factors are not known and should be taken into account in further studies.

FACTORS AFFECTING THE PARACELLULAR $\mathrm{K}^{+}$PERMEABILITY

Electron microscopy shows areas where only few strands are present in the zonulae occludentes between the epithelial cells at the surface of the proximal colon of the guinea pig. In the distal colon, the junctions between the cells are more compact, and significantly more strands separate the lumen from the intercellular space. ${ }^{21}$ Claude and Goodenough ${ }^{22}$ have postulated the relationship between the number of tight junctional strands and the transepithelial resistance. Frömter and Diamond ${ }^{23}$ have divided epithelia into the categories 'leaky' and 'tight'. The proximal as well as the distal colon may be termed moderately leaky or moderately tight; the transepithelial resistance is higher in the distal colon than in the proximal colon..$^{2+27}$

Fromm and Schultz ${ }^{28}$ have postulated that $\mathrm{K}^{+}$ transport in the colon is passive and occurs via the paracellular shunt mainly. This could not be confirmed by recent detailed studies. ${ }^{20}{ }^{29} \mathrm{We}$ had explained ${ }^{2}$ the low $\mathrm{K}^{+}$concentrations in the microclimate at the luminal surface by a high paracellular shunt for $\mathrm{K}^{+}$. Thus, a decrease of the paracellular shunt permeability should result in higher $\mathrm{K}^{+}$concentrations in the microclimate. Therefore, we have studied the influence of substances that are expected to alter paracellular shunt on $\mathrm{K}^{+}$concentrations in the microclimate.

Triaminopyrimidine is known to diminish the cation permeability of the paracellular shunt in the gallbladder. ${ }^{13}$ Compared to the control studies, addition of triaminopyrimidine resulted in $\mathrm{K}^{+}$concentrations in the microclimate more closely aligned to the $\mathrm{K}^{+}$concentration in the luminal solution (Fig 5). The mannitol clearance (Table I) was not decreased by triaminopyrimidine; mannitol passes tight junctions through 'neutral' pores; and triaminopyrimidine affects the cation selective pores in the tight junction by its positive charges.

An unselective increase of the paracellular shunt permeability with deoxycholic acid was previously shown for the rabbit colon. ${ }^{30} \mathrm{De}$ oxycholic acid significantly increased the mannitol clearance for the guinea pig colon (Table I). A missing effect of deoxycholic acid on the $\mathrm{K}^{+}$concentration in the microclimate of the proximal colon (Fig 4) may be due to an already high paracellular shunt in this section of the colon during control conditions. In the less leaky distal colon of the guinea pig, a rise in the shunt with deoxycholic acid led to lower $\mathrm{K}^{+}$concentrations in the microclimate, probably through a higher rate of $\mathrm{K}^{+}$diffusion across the shunt, especially at high $\mathrm{K}^{+}$concentrations in the luminal solution. After deoxycholic acid treat- ment, values of the distal colon became more like those of the less tight proximal colon. It was shown recently, for rabbit distal colon that bile salt stimulate $\mathrm{K}^{+}$secretion by increasing $\mathrm{Ba}^{++}$ blockable $\mathrm{K}^{+}$conductance in the apical membrane; ${ }^{31}$ the decrease of $\mathrm{K}^{+}$concentrations in the microclimate of the distal colon by the addition of deoxycholic acid in our studies is not in accordance with such a stimulation.

NORMAL POTASSIUM CONCENTRATIONS IN CONTENTS OF THE GUINEA PIG COLON

High $\mathrm{K}^{+}$concentrations are mostly found in contents of the colon in guinea pig. At a control diet mean $\mathrm{K}^{+}$concentrations were $60 \mathrm{mmol} / \mathrm{l}$ in the proximal colon and $30 \mathrm{mmol} / \mathrm{l}$ in the distal colon. At low potassium or high sodium concentrations in the diet values in the proximal colon were near $30 \mathrm{mmol} / \mathrm{l}$ and in the distal as low as $5-10 \mathrm{mmol} / \mathrm{l}$. At low sodium or high potassium diets values increase to $80-100 \mathrm{mmol} / \mathrm{/}^{32}$ (personal communication). $\mathrm{K}^{+}$concentrations in the test solutions (Table I) had been within the range found in colonic contents of guinea pigs.

We conclude that a high paracellular shunt in combination with a high pre-epithelial diffusion barrier may be important factors responsible for the low $\mathrm{K}^{+}$concentration in the microclimate at the luminal cell surface of guinea pig. This explanation is not in accordance with recent studies, where it was estimated that the $\mathrm{K}^{+}$ transport in the colon is mainly transcellular, only $10-20 \%$ may be paracellular. ${ }^{20}$ Furthermore, we have shown in recent experiments ${ }^{33}$ that the pre-epithelial diffusion resistance is not high enough to explain the observed high concentration gradients in the pre-epithelial area; obviously further unknown mechanisms are involved. Future simultaneous measurements of the microclimate and of transport characteristics of the epithelium may give us a better understanding. The heterogenous functions of enterocytes and of crypt cells, however, will still complicate interpretations.

This study was supported by grants of the Deutsche Forschungsgemeinschaft (EN 64/14 and 65/15). We thank PD Dr M Fromm and Dr G Rechkemmer for advice and helpful discussions, and $M$ Krause and G Becker for their skilled technical assistance.

Some of these findings were discussed at the 7th meeting of the European Intestinal Transport Group in Göteborg, Sweden and published in abstract form in Z Gastroenterol 1987; 25: 401-2.

1 Rechkemmer G, Wahl M, Kuschinsky W, Engelhardt Wv $\mathrm{pH}$-microclimate at the luminal surface of the intestina mucosa of guinea pig and rat. Pfiügers Arch 1986; 407: 33-40.

2 Engelhardt Wv, Kück U, Krause M. Potassium microclimat at the mucosal surface of the proximal and the distal colon of guinea pig. Pflügers Arch 1986; 407: 625-31.

3 Nellans HN, Frizzell RA, Schultz SG. Brush-border processe and transepithelial $\mathrm{Na}$ and $\mathrm{Cl}$ transport by rabbit ileum. $A m$ F Physiol 1974; 226: 1131-41.

4 Frizzell RA, Koch MJ, Schultz SG. Ion transport by rabbit colon, I. Active and passive components. $\mathcal{7}$ Membr Biol 1976; $27: 297-316$

5 Duffey ME. Intracellular $\mathrm{pH}$ and bicarbonate activities in rabbit colon. Am $\mathcal{F}$ Physiol 1984; 246: 558-61.

6 Moody GJ, Thomas JDR. Selective ion-sensitive electrodes. Watford, Marrow 1971: 275-302.

7 Dagostino $\mathrm{M}$, Lee CO. Neutral carrier $\mathrm{Na}$ ' and $\mathrm{Ca}$ ' selective microelectrodes for intracellular application. Biophys $\mathscr{J}$ 1982; 40: 199-207.

8 Robinson RA, Stokes RH. Electrolyte solutions. London: Butterworth, 1970: 479 .

9 Williams SE, Turnberg LA. Demonstration of a $\mathrm{pH}$ gradient across mucus adherent to rabbit gastric mucosa: evidence for 'mucus-bicarbonate' barrier. Gut 1981; 22: 94-6.

10 Argenzio RA, Whipp SC. Comparison of the effects of disodium ethylenediaminetetraacetate, theophylline, and 
deoxvcholic acid on colonic ion transport and permeability. Am $\tilde{y}$ Vet Res 1983; 44:1480-7.

11 I.ukie BE, Westergaard H, Dietschy JM. Validation of a chamber that allows measurement of both tissue uptake rates and unstirred laver thicknesses in the intestine under conditions of controlled stirring. Gastroenterologv 1974;67: $652-61$

12 Läuger P. Carrier mediated ion transport. Science 1972; 178: $2+30$

13 Moreno JH. Blockage of cation permeability across the tight junction of gallbladder and other leaky epithelia. Nature 1974; 251: 150-1.

14 McCabe RD, Cooke HJ, Sullivan I.P. Potassium transport by rabbit descending colon. Am 7 Phusiol 1982; 242: 81-6.

15 Wills NK, Biagi B. Active potassium transport by rabbi descending colon epithelium. I Membr Biol 1982;64: $195-203$

16 Plass H, Gridl A, Turnheim K. Absorption and secretion of potassium by rabbit descending colon. Pflïgers Arch 1986; 406: $509-19$.

17 Halm DR, Frizzell RA. Active K transport across rabbit distal colon: relation to $\mathrm{Na}$ absorption and $\mathrm{Cl}$ secretion. $\mathrm{Am}$ Phviol 1986; 251: 252-67.

18 Foster ES, Havslett JP. Binder HJ. Mechanism of active potassium absorption and secretion in the rat colon. Am.F

19 McCabe RD, Smith PL, Sullivan I.P. Ion transport by rabbit descending colon: mechanisms of trans-epithelial potassium

20 Smith PL, McCabe RD. Mechanism and regulation of tran cellular potassium transport by the colon. Am f Physiol $1984 ; 247: 445-56$

21 Luciano L, Reale E, Rechkemmer G, Engelhardt Wv. Struc ture of zonulae occludentes and the permeability of the epithelium to short-chain fatty acids in the proximal and the distal colon of guinea pig $7 \mathrm{Membr}$ Biol 1984; 82:115-56.

22 Claude P, Goodenough DA. Fracture faces of zonulae occlu- dentes from 'tight' and 'leaky' epithelia. $\mathcal{F}$ ('ell Biol 1973; 58: $390-400$

23 Frömter E, Diamond J. Route of passive ion permeation in epithelia. Nature New Biol 1972; 235: 9-13.

24 Fromm M, Hegel U. Segmental heterogeneity of epithelia transport in rat large intestine. Pflügers Arch 1978; 378: 71-83.

25 Powell DW. Barrier function of epithelia. Am F Phvsiol 1981; 241: $275-88$

26 Clauss W, Schäfer H, Horch I, Hörnicke H. Segmental differences in electrical properties and $\mathrm{Na}$-transport of rabbit caecum, proximal and distal colon in vitro. P'flügers rabit caecum, proxima

27 Rechkemmer G, Halm DR, Frizzell RA. Differences in electrolyte transport mechanisms in the guinea pig proximal and distal colon. Pflügers Arch 1988; 411: 80 .

28 Fromm M, Schultz SG. Potassium transport across rabbit descending colon in vitro: evidence for single-file diffusion through a paracellular pathway. 7 Membr Biol 1981; 63: 93-8

29 Binder HJ, Sandle GI. Electrolyte absorption and secretion in the mammalian colon. In: Johnson I.R, ed. Phvsiology of the gastrointestinal tract, vol 2. New York: Raven Press, 1987: gastromtestind $1389-418$.

30 Freel RW, Hatch M, Earnest DL, Goldner AM. Role of tight junctional pathways in bile salt-induced increases in colonic permeability. Am.7 Physiol 1983; 245: 816-23.

31 Freel RW. Dihydroxy bile salt-induced secretion of rubidium ion across the rabbit distal colon. Am F P hvsiol 1987; 252 $554-61$.

32 Rechkemmer G, Krause M, Becker G, Engelhardt Wv. Konzentrationen von Elektrolyten und kurzkettigen Fettsäuren im Magen-Darm-Trakt des Meerschweinchen bei Normaldiät und Na-armer Diät. DTW 1987;94: $12-5$.

33 Guth D, Engelhardt Wv. Is gastro-intestinal mucus an ionselective harrier? In: Chantler E, ed. Mucus and related topics. Soc Exp Biol. 1989 (In press). 